\title{
KEADILAN ORGANISASIONAL, KOMITMEN ORGANISASIONAL, DAN KINERJA KARYAWAN
}

\author{
Harris Kristanto \\ Program Manajemen Bisnis Universitas Kristen Petra \\ Jalan Siwalankerto 121-131, Surabaya 60236, Indonesia \\ E-mail: kristanto_harris@ymail.com
}

\begin{abstract}
Abstrak
Sumber daya manusia merupakan hal yang perlu diperhatikan dalam perusahaan. Penelitian ini bertujuan untuk mengetahui pengaruh keadilan organisasional terhadap kinerja karyawan dengan komitmen organisasional sebagai variabel intervening. Penelitian dilakukan di CV Tanaya Fiberglass, Surabaya, dengan sampel sebanyak 38 karyawan. Data dianalisis secara kuantitatif dengan analisis deskriptif dan analisis jalur. Hasil menunjukkan bahwa keadilan organisasional berpengaruh positif terhadap komitmen organisasional Keadilan organisasional berpengaruh positif terhadap kinerja karyawan dengan komitmen organisasional sebagai variabel intervening. Keadilan organisasional juga berpengaruh positif terhadap kinerja karyawan.
\end{abstract}

Kata kunci: Keadilan organisasional, komitmen organisasional, kinerja karyawan

\begin{abstract}
Human resource is an aspect that need to be considered in the company. The objective of this research was to determine the influence of organizational justice towards employee performance with organizational commitment as an intervening variable. The study was conducted in CV Tanaya Fiberglass, Surabaya, with sample of 38 employees. Data was analyzed quantitatively using descriptive analysis and path analysis. The results showed that organizational justice influenced organizational commitment. Organizational justice influenced employee performance with organizational commitment as an intervening variable. Organizational justice influenced employee performance.
\end{abstract}

\section{Keywords: Organizational justice, organizational commitment, employee performance}

\section{Pendahuluan}

Industri fiberglass merupakan industri yang cukup berkembang di dunia maupun di Indonesia. Fiberglass merupakan salah satu bahan industri yang dapat digunakan sebagai komponen dalam bangunan. Gambar 1 menunjukkan perkembangan industri fiberglass di dunia maupun di Indonesia yang cenderung meningkat dari waktu ke waktu. CV Tanaya fiberglass merupakan perusahaan yang bergerak di bidang fiberglass.

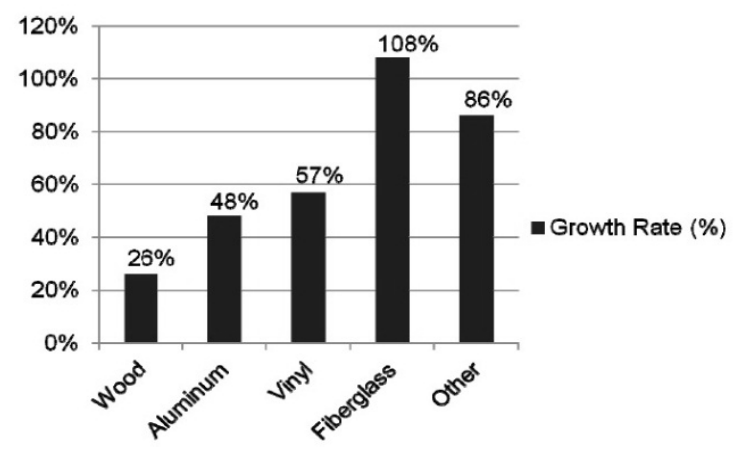

Gambar 1. Perkembangan permintaan fiberglass di Indonesia periode 2011/2012

Sumber: American Architectural Manufacturer Association, 2012
Permintaan fiberglass yang terus meningkat hendaknya diimbangi dengan kinerja perusahaan yang terus meningkat. Satu sisi, sumber daya manusia dapat menjadi salah satu keunggulan kompetitif bagi perusahaan (Moran \& Brightman, 2000). Akan tetapi, di sisi lain sumber daya manusia akan menjadi beban bagi perusahaan apabila tidak dilakukan pengelolaan dengan tepat (Zopiatis \& Constanti, 2007). Masalah yang timbul akibat tidak dikelolanya sumber daya manusia, antara lain: (1) Tidak harmonisnya hubungan antara pekerja dengan pemberi kerja (Galuh, 2012; Widiyanto, 2014) (2) Kinerja karyawan yang tidak meningkat bahkan turun (Purwanto, 2013) dan (3) Kepentingan perusahaan dikesampingkan dibandingkan dengan kepentingannya sendiri (Purwanto, 2013). Menurut Neely, Adams, and Crowe (2001), sumber daya manusia merupakan salah satu aspek dari keberhasilan perusahaan. Lebih lagi, Sutanto (1999) menyatakan bahwa kinerja perusahaan berhubungan erat dengan kinerja karyawan.

Teori mengenai manajemen sumber daya manusia sudah berkembang dari waktu ke waktu. Personnel management mulai diperkenalkan sejak tahun 1940 (Fleming, 2000). Tujuan utama pengelolaan dengan menggunakan personnel management adalah 
untuk mengatur pekerja, baik secara administratif dan operasional, sehingga dapat seefektif mungkin berkontribusi bagi perusahaan. Lambat laun, personnel management mulai digantikan oleh manajemen sumber daya manusia (human resource management) yang lebih kompleks dan terintegrasi. Salah satu alasannya adalah personnel management tidak memberikan keadilan bagi para pekerja (Long, 1985). Manajemen sumber daya manusia (MSDM) menjanjikan tiga hal yang tidak tercakup dalam personnel management, yaitu: (1) Hubungan karyawan dengan strategi perusahaan (2) Berusaha mendapatkan komitmen pekerja daripada sekedar penyelesaian kerja, dan (3) Memperhatikan aspek perilaku pekerja.

Hal yang cukup penting dalam MSDM adalah komitmen organisasional dan keadilan organisasional (salah satu bentuk aspek perilaku pekerja). Adanya keadilan organisasional membedakan manajemen sumber daya manusia dengan personnel management, yang pernah bermasalah dengan ketidakadilan (Long, 1985). Aspek keadilan organisasional menjadi sangat penting dalam kehidupan organisasi, karena apabila keadilan tersebut tidak ada, maka dapat menyebabkan turunnya komitmen, terjadinya kejahatan di lingkungan kerja, dan adanya keinginan untuk melakukan protes (Skitka \& Bravo, 2005). Hasil penelitian menyatakan bahwa keadilan organisasional mempunyai pengaruh yang positif terhadap komitmen organisasional (Pareke \& Suryana, 2009; Jawad, Raja, Abraiz, \& Tabassum, 2012; Yazicioglu \& Topaloglu, 2009). Tidak hanya itu, keadilan organisasional juga ditemukan memberikan pengaruh positif terhadap kinerja (Nasurdin \& Khuan, 2007; Suliman \& Kathairi, 2013).

Lebih dari itu, komitmen merupakan salah satu faktor yang menjadi pembeda manajemen sumber daya manusia dengan personnel management. Konsep komitmen dikembangkan oleh Meyer and Allen (1997) yang membagi komitmen menjadi tiga komponen. Sejak saat itu, penelitian mengenai komitmen organisasional mulai banyak dilakukan, seperti yang dilakukan oleh Tobing (2009), Atmojo (2012), dan Sutanto (1999). Komitmen organisasional oleh Gibson, Ivancevich, Donnelly, and Konopaske (2012) diartikan sebagai rasa keterlibatan dan kesetiaan yang diekspresikan pekerja terhadap suatu organisasi. Dengan adanya komitmen terhadap organisasi, kinerja karyawan dapat meningkat, karena pekerja akan bekerja lebih dengan sepenuh hati. Beberapa penelitian juga menyatakan bahwa komitmen merupakan faktor yang mempengaruhi kinerja. Penelitian Tobing (2009) dan Atmojo (2012) menyatakan bahwa komitmen organisasional secara positif berpengaruh terhadap kinerja karyawan. Sutanto (1999) menyatakan bahwa komitmen terhadap supervisor lebih mempunyai pengaruh positif terhadap kinerja karyawan daripada komitmen organisasional.

CV Tanaya Fiberglass merupakan perusahaan yang bergerak di industri fiberglass dan sedang mengembangkan usahanya dengan lingkup pasar yang lebih luas. Oleh sebab itu, manajemen sumber daya manusia yang baik sangat dibutuhkan. Terutama di bagian produksi, karena hal utama yang diperjualbelikan oleh CV Tanaya Fiberglass adalah barang. Apabila pengerjaan pada waktu produksi tidak dilakukan dengan baik, maka barang yang dijual ke konsumen juga tidak mempunyai kualitas yang baik atau sesuai dengan harapan. Hal tersebut akan berpengaruh langsung terhadap minat beli konsumen (Saidani \& Arifin, 2012). Perlu dibutuhkan kinerja yang baik dan maksimal dari karyawan dan manajemen sumber daya manusia, yang mana keadilan organisasional dan komitmen organisasional termasuk di dalamnya, untuk membuat sumber daya manusia menjadi keuntungan bagi perusahaan mendasari penelitian ini penting untuk dilakukan. Oleh karena itu, dilakukanlah penelitian untuk menguji pengaruh keadilan organisasional terhadap kinerja karyawan dengan komitmen organisasional sebagai variabel intervening.

\section{Keadilan Organisasional}

Gibson et al. (2012) mendefinisikan keadilan organisasional sebagai suatu tingkat di mana seorang individu merasa diperlakukan sama di organisasi tempat dia bekerja. Definisi lain mengatakan bahwa keadilan organisasional adalah persepsi adil dari seseorang terhadap keputusan yang diambil oleh atasannya (Colquitt, LePine, \& Wesson, 2009).

Moorman (1991) membagi keadilan organisasional menjadi tiga, yaitu keadilan distributif, keadilan prosedural, dan keadilan interaksional. Colquitt et al. (2001) mengemukakan bahwa keadilan organisasional mempunyai empat tipe, yaitu keadilan distributif, keadilan prosedural, keadilan interpersonal, dan keadilan informasional. Tipe keadilan organisasional menurut Moorman dan Colquitt masing-masing mempunyai keunggulannya masing-masing (dalam Miller, Konopaske, \& Byrne, 2012). Teori keadilan Colquitt tersebut sekarang lebih sering digunakan ketimbang teori keadilan organisasional yang lain ( $\mathrm{Li} \&$ Cropanzano, 2009).

Menurut Dyna and Graham (2005) (dalam Carlis, 2011), keadilan organisasi dapat diketahui dengan mengukur tiga hal, yaitu 1) Keadilan yang berkaitan dengan kewajaran alokasi sumber daya. 
Organisasi dapat dikatakan adil oleh karyawan, jika memberikan gaji sesuai dengan hasil kerja yang dilakukan oleh karyawan. Apabila perbandingan antara gaji yang diterima dengan hasil kerja yang dilakukan karyawan dirasa tidak sebanding, maka karyawan akan merasa bahwa tidak terjadi keadilan. 2) Keadilan dalam proses pengambilan keputusan. Organisasi dapat dikatakan adil oleh karyawan apabila dalam pengambilan keputusan, karyawan diberikan kesempatan untuk menyuarakan pendapat dan pandangannya. Selain itu, setelah pengambilan keputusan dilakukan, apabila pelaksanaan keputusan tersebut dinilai sama pada tiap karyawan, maka karyawan akan merasa bahwa terjadi keadilan. 3) Keadilan dalam persepsi kewajaran atas pemeliharaan hubungan antar pribadi. Organisasi dapat dikatakan adil oleh karyawan apabila hubungan antar atasan dengan bawahan baik, seperti mendapatkan perlakuan yang baik dan sewajarnya. Selain itu, kejujuran dan kebenaran informasi yang didapatkan dari atasan juga mempengaruhi persepsi keadilan organisasional dari karyawan.

\section{Komitmen Organisasional}

Menurut Hellriegel and Slocum (2004), komitmen organisasional adalah tingkat keterlibatan karyawan dalam organisasi dan mempunyai identitas yang sama dengan organisasi. Colquitt et al. (2009) mendefinisikan komitmen organisasional sebagai keinginan dari karyawan untuk menjadi bagian dan anggota di suatu organisasi.

Porter et al. (1974) (dalam Amin, Yusnita, Ibrahim, \& Muda, 2013) mengemukakan mengenai indikator dari komitmen organisasional. Indikator tersebut ada tiga, yaitu 1) A strong belief in and acceptance of the organization's goals and values (Acceptance). Penerimaan terhadap nilai dan tujuan organisasi. Artinya adalah ada kesesuaian antara nilai yang dianut oleh karyawan dengan organisasi. Apabila karyawan merasakan tujuan organisasi dapat memenuhi keinginannya, maka karyawan akan memberikan sepenuhnya komitmen terhadap organisasi. 2) $A$ willingness to exert considerable effort on behalf of the organization (Willingness). Berkaitan dengan kesediaan untuk berusaha sungguh-sungguh atas nama organisasi. Karyawan dapat merasa bertanggung jawab untuk membangun organisasi dan merasa senang dengan organisasi. 3) A strong desire to maintain membership in the organization (Maintain). Keinginan untuk mempertahankan keanggotaan dalam organisasi atau menjadi bagian dari organisasi. Karyawan bersedia terlibat dalam organisasi dan memperkokoh kedudukannya supaya merasakan dirinya diperlukan dan dihargai. Hal ini akan memberikan komitmen kerja yang tinggi dalam diri karyawan.

\section{Kinerja Karyawan}

Kinerja adalah perbandingan antara prestasi kerja, yakni perbandingan antara hasil kerja dengan standar yang diharapkan (Dessler, 2005). Menurut definisi tersebut, kinerja fokus pada hasil kerjanya. Menurut Siagian (2005) kinerja adalah konsep yang bersifat universal yang merupakan efektivitas operasional karyawan, bagian organisasi dan bagian yang berdasar standar dan kriteria yang ditetapkan. Kane (1993) (dalam Harahap, 2010) menjelaskan, kinerja sebagai rekaman hasil kerja yang diperoleh karyawan tertentu melalui kegiatan dalam kurun waktu tertentu.

Menurut Supardi (1999) (dalam Ginting, 2012), indikator penilaian kinerja ada tujuh poin, yaitu 1) Kualitas kerja: Kualitas kerja meliputi akurasi ketelitian, kerapian, melaksanakan pekerjaan, mempergunakan dan memelihara alat kerja, keterampilan dan kecakapan melaksanakan tugas. 2) Kuantitas Kerja: Kuantitas kerja meliputi keluaran dan target dari pekerjaan. 3) Pengetahuan: Pengetahuan adalah kemampuan seorang karyawan sehubungan dengan hal-hal yang berhubungan dengan tugas dan prosedur kerja, penggunaan alat-alat kerja maupun kemampuan teknis atau pekerjaan. 4) Penyesuaian pekerjaan: Penyesuaian pekerjaan ditinjau dari kemampuan karyawan dalam melaksanakan tugasnya di luar pekerjaan maupun adanya tugas baru serta kecepatannya berpikir dan bertindak dalam bekerja. 5) Keandalan: Keandalan adalah kemampuan karyawan dalam melaksanakan tugas, misalnya saat melaksanakan prosedur, peraturan kerja, inisiatif, kedisiplinan, dan lain-lain. 6) Hubungan kerja: Hubungan kerja dapat dilihat dari sikap karyawan terhadap lainnya, sikap karyawan terhadap aturan, dan kesedian dalam menerima perubahan-perubahan kerja. 7) Keselamatan kerja: Keselamatan kerja menyangkut bagaimana perhatian karyawan pada keselamatan kerja.

\section{Kerangka Berpikir}

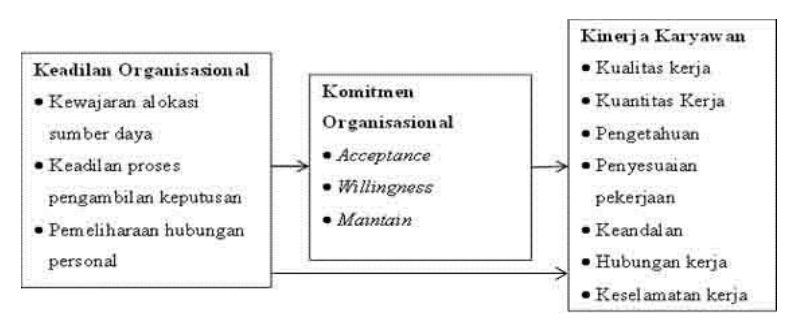

\section{Gambar 2. Kerangka Berpikir}

Sumber: Carlis, 2011; Amin et al., 2013; Ginting, 2012; Suliman and Kathairi, 2013. 


\section{Hipotesis}

Pareke dan Suryana (2009) yang meneliti Universitas di Propinsi Bengkulu. Jawad et al. (2012) yang meneliti karyawan Universitas termasuk dosen; dan Yazicioglu and Topaloglu (2009) yang meneliti karyawan perusahaan yang dipilih secara acak menyatakan bahwa keadilan organisasional mempunyai pengaruh yang positif dan signifikan terhadap komitmen organisasional. Artinya, semakin tinggi keadilan organisasional di suatu perusahaan, maka komitmen organisasional karyawan juga semakin tinggi. Oleh karena itu, maka disusun hipotesis pertama, yaitu $H_{l}$ : Keadilan organisasional berpengaruh terhadap komitmen organisasional.

Nasurdin and Khuan (2007) yang meneliti karyawan industri komunikasi di Malaysia membuktikan bahwa keadilan distributif dan keadilan prosedural mempunyai pengaruh positif terhadap kinerja karyawan. Atmojo (2012) yang meneliti karyawan perusahaan listrik dan Tobing (2009) yang meneliti karyawan perusahaan perkebunan menunjukkan adanya pengaruh positif dan signifikan komitmen organisasional dengan kinerja karyawan. Oleh karena itu, maka disusun hipotesis kedua, yaitu $\mathrm{H}_{2}$ : Keadilan organisasional dengan komitmen organisasional sebagai variabel intervening berpengaruh terhadap kinerja karyawan.

Suliman and Kathairi (2013), menggunakan komitmen organisasional sebagai variabel intervening pengaruh keadilan organisasional terhadap kinerja. Hasilnya menyatakan bahwa keadilan organisasional melalui komitmen organisasional sebagai variabel intervening mempunyai pengaruh terhadap kinerja. Oleh karena itu, maka disusun hipotesis ketiga, yaitu $\mathrm{H}_{3}$ : Keadilan organisasional berpengaruh terhadap kinerja karyawan.

\section{Metode Penelitian}

\section{Jenis Penelitian}

Penelitian ini merupakan penelitian kuantitatif. Penelitian kuantitatif menurut Noor (2011) adalah penelitian untuk menguji teori-teori tertentu dengan cara meneliti hubungan antar variabel. Alasan menggunakan penelitian kuantitatif adalah penelitian ini bertujuan untuk mengetahui pengaruh keadilan organisasional terhadap kinerja karyawan dengan komitmen organisasional sebagai variabel intervening, sehingga penelitian kuantitatif cocok dengan penelitian ini.

\section{Definisi Operasional}

Definisi keadilan organisasional dalam penelitian ini adalah persepsi adil dari seseorang terhadap keputusan yang diambil oleh atasannya. Keadilan organisasional memiliki tiga indikator, yaitu (1) Alokasi sumber daya (persepsi adil terkait dengan perbandingan gaji yang diterima dengan hasil kerja yang dilakukan), (2) Kewajaran prosedur (persepsi adil terkait dengan proses pengambilan keputusan dan pelaksanaan keputusan kepada karyawan), dan (3) Hubungan personal (persepsi adil terhadap perilaku yang diterima karyawan dari atasannya atau otoritas yang lebih tinggi).

Definisi komitmen organisasional adalah keinginan dari karyawan untuk menjadi bagian dan anggota di suatu organisasi. Komitmen organisasional mempunyai tiga indikator, yaitu: (1) Acceptance (kesesuaian antara nilai yang dianut oleh karyawan dengan nilai yang ada dalam organisasi) (2) Willingness (kebersediaan untuk berusaha sungguh-sungguh atas nama organisasi) dan (3) Maintain (keinginan untuk mempertahankan keanggotaan dalam organisasi).

Definisi kinerja karyawan adalah rekaman hasil kerja yang diperoleh karyawan tertentu melalui kegiatan dalam kurun waktu tertentu. Kinerja mempunyai tujuh dimensi untuk diukur, yaitu: (1) Kualitas kerja (akurasi ketelitian, kerapian, melaksanakan pekerjaan, mempergunakan dan memelihara alat kerja, keterampilan dan kecakapan melaksanakan tugas) (2) Kuantitas Kerja (keluaran dan target dari pekerjaan) (3) Pengetahuan (kemampuan seorang karyawan sehubungan dengan hal-hal yang berhubungan dengan tugas dan prosedur kerja, penggunaan alat-alat kerja maupun kemampuan teknis atau pekerjaan) (4) Penyesuaian pekerjaan (kemampuan karyawan dalam melaksanakan tugasnya di luar pekerjaan maupun adanya tugas baru serta kecepatannya berpikir dan bertindak dalam bekerja) (5) Keandalan (kemampuan karyawan dalam melaksanakan tugas, misalnya saat melaksanakan prosedur, peraturan kerja, inisiatif, kedisiplinan), (6) Hubungan kerja (sikap karyawan terhadap lainnya, sikap karyawan terhadap aturan, dan kesediaan dalam menerima perubahan-perubahan kerja) dan (7) Keselamatan kerja (bagaimana perhatian karyawan pada keselamatan kerja). Operasionalisasi variabel selengkapnya dapat dilihat pada Tabel 1 .

\section{Teknik Penentuan Sampel}

Noor (2011) mendefinisikan sampel sebagai mengambil elemen secukupnya dari populasi, yang dapat mewakili sifat dan karakteristik dari populasi. Sampel pada penelitian ini menggunakan teknik nonprobability sampling, yaitu saturation sampling atau sampel jenuh. Sampel yang digunakan sebanyak 38 karyawan di bagian produksi. Selain itu, teknik ini dipilih karena jumlah populasi relatif kecil, yaitu kurang dari 100 orang (Noor, 2011). 
Tabel 1

Definisi Operasional Variabel

\begin{tabular}{|c|c|c|c|c|}
\hline Variabel & Dimensi & Indikator & Definisi Operasional & Skala Ukuran \\
\hline \multirow[t]{5}{*}{$\begin{array}{l}\text { Keadilan } \\
\text { organisasional }\end{array}$} & $\begin{array}{l}\text { Kewajaran alokasi } \\
\text { sumber daya }\end{array}$ & $\begin{array}{l}\text { - Perbandingan gaji dengan } \\
\text { pekerjaan }\end{array}$ & $\begin{array}{l}\text { Perbandingan gaji yang diterima } \\
\text { dengan hasil kerja dan usaha yang } \\
\text { dilakukan }\end{array}$ & likert \\
\hline & \multirow[t]{2}{*}{$\begin{array}{l}\text { Keadilan proses } \\
\text { pengambilan } \\
\text { keputusan }\end{array}$} & $\begin{array}{l}\text { - Kesamaan pelaksanaan } \\
\text { keputusan perusahaan }\end{array}$ & $\begin{array}{l}\text { Pelaksanaan keputusan perusahaan } \\
\text { kepada tiap karyawan dilakukan } \\
\text { dengan sama }\end{array}$ & likert \\
\hline & & $\begin{array}{l}\text { - Kesempatan dalam } \\
\text { menyuarakan pendapat }\end{array}$ & $\begin{array}{l}\text { Adanya kesempatan yang sama bagi } \\
\text { karyawan untuk menyuarakan } \\
\text { pendapat }\end{array}$ & likert \\
\hline & \multirow[t]{2}{*}{ Hubungan personal } & $\begin{array}{l}\text { - Perlakuan atasan } \\
\text { terhadap karyawan }\end{array}$ & $\begin{array}{l}\text { Kesamaan perilaku yang diterima } \\
\text { karyawan dari atasan }\end{array}$ & likert \\
\hline & & $\begin{array}{l}\text { - Keterbukaan atasan } \\
\text { kepada bawahan }\end{array}$ & $\begin{array}{l}\text { Adanya informasi atau hal lain yang } \\
\text { ditutup-tutupi oleh atasan terhadap } \\
\text { karyawan }\end{array}$ & likert \\
\hline \multirow[t]{4}{*}{$\begin{array}{l}\text { Komitmen } \\
\text { organisasional }\end{array}$} & Acceptance & $\begin{array}{l}\text { - Kesesuaian nilai } \\
\text { perusahaan dengan nilai } \\
\text { karyawan }\end{array}$ & $\begin{array}{l}\text { Kesesuaian antara nilai yang dianut } \\
\text { oleh karyawan dengan nilai yang ada } \\
\text { dalam organisasi }\end{array}$ & likert \\
\hline & Willingness & $\begin{array}{l}\text { - Kebersediaan untuk } \\
\text { organisasi }\end{array}$ & $\begin{array}{l}\text { Kebersediaan karyawan untuk } \\
\text { berusaha sungguh-sungguh atas nama } \\
\text { organisasi }\end{array}$ & likert \\
\hline & \multirow[t]{2}{*}{ Maintain } & $\begin{array}{l}\text { - Kebanggaan terhadap } \\
\text { perusahaan }\end{array}$ & $\begin{array}{l}\text { Karyawan merasa bangga terhadap } \\
\text { perusahaan tempat kerjanya }\end{array}$ & likert \\
\hline & & $\begin{array}{l}\text { - Keinginan untuk } \\
\text { bertahan di perusahaan }\end{array}$ & $\begin{array}{l}\text { Keinginan untuk mepertahankan } \\
\text { keanggotaan dalam organisasi }\end{array}$ & likert \\
\hline \multirow[t]{9}{*}{$\begin{array}{l}\text { Kinerja } \\
\text { karyawan }\end{array}$} & Kualitas kerja & - Ketelitian dan kerapihan & $\begin{array}{l}\text { Ketelitian dan kerapian dalam } \\
\text { melaksanakan tugas }\end{array}$ & likert \\
\hline & Kuantitas Kerja & - Pemenuhan kuota & $\begin{array}{l}\text { Kesesuaian jumlah produk yang } \\
\text { dihasilkan oleh karyawan dengan } \\
\text { harapan perusahaan }\end{array}$ & likert \\
\hline & Pengetahuan & $\begin{array}{l}\text { - Kemampuan } \\
\text { melaksanakan pekerjaan }\end{array}$ & $\begin{array}{l}\text { Kemampuan karyawan sehubungan } \\
\text { dengan pekerjaan sehingga dapat } \\
\text { melaksanakan pekerjaan dengan baik }\end{array}$ & likert \\
\hline & \multirow[t]{2}{*}{$\begin{array}{l}\text { Penyeseuaian } \\
\text { pekerjaan }\end{array}$} & $\begin{array}{l}\text { - Kemampuan } \\
\text { mengerjakan pekerjaan } \\
\text { lain }\end{array}$ & $\begin{array}{l}\text { Kemampuan karyawan dalam } \\
\text { melaksanakan tugas di luar } \\
\text { pekerjaannya }\end{array}$ & likert \\
\hline & & $\begin{array}{l}\text { - Penyesuaian dengan } \\
\text { keputusan baru }\end{array}$ & $\begin{array}{l}\text { Kemampuan karyawan dalam } \\
\text { menyesuaikan diri dengan kebijakan } \\
\text { baru perusahaan }\end{array}$ & likert \\
\hline & \multirow[t]{2}{*}{ Keandalan } & $\begin{array}{l}\text { - Kemampuan melakukan } \\
\text { prosedur }\end{array}$ & $\begin{array}{l}\text { Kemampuan karyawan dalam } \\
\text { melaksanakan prosedur. }\end{array}$ & likert \\
\hline & & $\begin{array}{l}\text { - Kemampuan mencari } \\
\text { solusi }\end{array}$ & $\begin{array}{l}\text { Kemampuan karyawan dalam } \\
\text { mencari solusi masalah teknis. }\end{array}$ & likert \\
\hline & Hubungan kerja & $\begin{array}{l}\text { - Ketaatan terhadap } \\
\text { prosedur }\end{array}$ & $\begin{array}{l}\text { Sikap karyawan terhadap aturan dan } \\
\text { prosedur yang ada dalam perusahaan }\end{array}$ & likert \\
\hline & Keselamatan kerja & $\begin{array}{l}\text { - Pemahaman aturan } \\
\text { keselamatan kerja }\end{array}$ & $\begin{array}{l}\text { Perhatian dan pemahaman karyawan } \\
\text { terhadap aturan keselamatan kerja }\end{array}$ & likert \\
\hline
\end{tabular}

\section{Teknik Pengumpulan Data}

Data dalam penelitian ini dikumpulkan dengan dua cara, yaitu melalui kuesioner dan wawancara. Kuesioner didefinisikan sebagai teknik pengumpulan data dengan memberikan atau menyebarkan daftar pertanyaan kepada responden dengan harapan memberikan respons atas daftar pertanyaan tersebut (Noor, 2011). Kuesioner dalam penelitian ini menggunakan penskalaan (memberikan pilihan jawaban), yaitu skala likert. Skala likert yang digunakan adalah 1 mewakili sangat tidak setuju, 2 mewakili tidak setuju, 3 mewakili netral, 4 mewakili setuju, dan 5 mewakili sangat setuju. Kuesioner seperti ini disebut dengan fixed-alternatifs questionnaire atau close-ended questionnaire, yaitu kuesioner yang sudah mempunyai pilihan jawaban (Zikmund, Babin, Carr, \& Griffin, 2010). Kuesioner disebarkan kepada 38 orang karyawan di bagian produksi untuk mendapatkan data terkait keadilan organisasional, komitmen organisasional, dan kinerja karyawan. Cara untuk mendapatkan keakuratan data, kuesioner juga diberikan kepada 
owner, sebagai orang yang mengepalai bagian produksi, untuk mendapatkan data mengenai kinerja karyawan.

Menurut Noor (2011), wawancara merupakan salah satu teknik pengumpulan data yang dilakukan dengan berhadapan secara langsung dengan yang diwawancarai tetapi dapat juga diberikan daftar pertanyaan dahulu untuk dijawab pada kesempatan lain. Wawancara dalam penelitian ini berguna untuk mendapatkan informasi seperti profil perusahaan, struktur organisasi, dan manajemen sumber daya manusia.

\section{Teknik Analisis Data}

\section{Validitas dan Reliabilitas}

Teknik yang digunakan sebagai uji keabsahan data adalah uji validitas dan uji reliabilitas. Reliabilitas menyatakan kekonsistenan butir pertanyaan dari kuesioner, sedangkan validitas menyatakan keakuratan kuesioner dalam mewakili konsep (Zikmund $e t$ al., 2010). Validitas adalah tingkat kebenaran kesimpulan, inferensi, atau proposisi dari hasil penelitian. Dalam penelitian ini, uji reliabilitas dilakukan dengan menggunakan Alpha Cronbach dan uji validitas dilakukan dengan menggunakan perbandingan antara $r_{\text {hitung }}$ dengan $r_{\text {tabel }}$. Suatu variabel dikatakan reliabel apabila memiliki nilai alpha cronbach lebih dari 0,70 (Ghozali, 2012), sedangkan variabel dikatakan valid apabila $r_{\text {hitumg }}$ lebih besar dari $r_{\text {tabel }}$.

\section{Uji Asumsi Klasik}

Uji multikolinearitas bertujuan untuk menguji adanya hubungan antara variabel independen dalam model. Model yang baik tidak menunjukkan adanya gejala multikolinearitas antar variabel independennya (Ghozali, 2012). Dalam penelitian ini, uji multikolinearitas diketahui dengan melihat nilai $V I F$ (variance inflation factor). Apabila nilai $V I F<10$, maka dianggap tidak terjadi multikolinearitas.

Uji autokorelasi bertujuan untuk menguji adanya korelasi antara kesalahan pengganggu pada periode $t$ dengan kesalahan pengganggu pada periode $t-1$ (sebelumnya). Apabila ada korelasi, maka timbul masalah autokorelasi (Ghozali, 2012). Dalam penelitian ini, uji autokorelasi yang digunakan adalah uji Durbin -Watson $(d)$. Tabel 2 menyatakan keputusan ada tidaknya autokorelasi, dengan $d u$ adalah batas atas.

Uji heteroskedastisitas bertujuan untuk menguji adanya ketidaksamaan varians dari residual satu pengamatan ke pengamatan lain. Apabila varians residual pengamatan satu dengan yang lain sama, maka disebut homokedastisitas atau tidak terjadi heteroskedastisitas. Model yang baik tidak terjadi heteroskedastisitas (Ghozali, 2012). Dalam penelitian ini, uji heteroskedastisitas dilakukan dengan melihat grafik plot antara ZPRED dengan SRESID. Apabila titiktitik pada plot menyebar, maka tidak terjadi heteroskedastisitas.

Tabel 2

Keputusan Terjadinya Autokorelasi

\begin{tabular}{lc}
\hline \multicolumn{1}{c}{ Keputusan } & Syarat \\
\multicolumn{1}{c}{ Autokorelasi } & \\
\hline $\begin{array}{l}\text { Tidak ada autokorelasi } \\
\text { positif }\end{array}$ & $0<d<d l$ atau $d l \leq d \leq d u$ \\
Tidak ada autokorelasi & \\
negatif & $4-d l<d<4$ atau $4-d u \leq d \leq 4-d l$ \\
Tidak ada autokorelasi & \\
positif maupun negatif & $d u<d<4-d u$ \\
\hline Sumber: &
\end{tabular}

Sumber: Ghozali, 2012

Uji normalitas berguna untuk mengetahui apakah residual berdistribusi normal atau tidak. Dalam penelitian ini, uji normalitas dilakukan dengan melihat grafik histogram dan normal probability plot. Apabila pada normal probability plot sebaran mengikuti pola garis lurus diagonal, maka uji normalitas dipenuhi (Ghozali, 2012). Selain itu, uji normalitas dipertegas dengan uji Kolmogorov-Smirnov. Apabila tingkat signifikansi pada uji Kolmogorov-Smirnov lebih dari 0,05 , maka memenuhi uji normalitas (Ghozali, 2012).

\section{Analisis Deskriptif}

Statistik deskriptif adalah statistik yang menggambarkan fenomena atau karakteristik data (Puspowarsito, 2008). Dalam penelitian ini, statistik deskriptif ditampilkan dengan menunjukkan mean (rata-rata) dan standar deviasi.

\section{Analisis Jalur (Path Analysis)}

Teknik analisis yang digunakan analisis jalur (path analysis). Analisis jalur merupakan pengembangan dari regresi yang dapat menguji pengaruh secara langsung (direct effect) maupun tidak langsung (indirect effect) dengan adanya variabel intervening. Dalam penelitian ini, analisis jalur digunakan untuk menguji pengaruh dengan adanya variabel intervening. Analisis jalur untuk menguji pengaruh secara tidak langsung digambarkan pada Gambar 3.

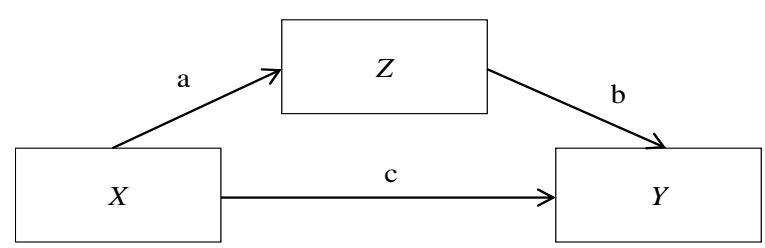

Gambar 3. Uji Indirect Effect dengan Analisis Jalur Sumber: Ghozali, 2012 
$X$ merupakan variabel independen, $Y$ merupakan variabel dependen, dan $Z$ merupakan variabel intervening. Dalam uji pengaruh secara tidak langsung, dapat dibentuk tiga persamaan umum, yaitu (Ghozali, 2012):

a. $Y=\alpha 1+c X$ untuk menguji pengaruh $X$ terhadap $Y$ secara langsung,

b. $Z=\alpha 2+a X$ untuk menguji pengaruh $X$ terhadap $Z$, dan

c. $Y=\alpha 3+c^{\prime} X+b Z$ untuk menguji pengaruh $X$ terhadap $Y$ melalui $Z$

Kuatnya pengaruh tidak langsung (dengan adanya variabel Z) dihitung dengan mengalikan $a$ dengan $b$ atau dengan menghitung selisih koefisien $X$ saat dilakukan uji pengaruh langsung dengan uji pengaruh tidak langsung $\left(c-c^{\prime}\right)$. Variabel independen $(X)$ dalam penelitian ini adalah keadilan organisasional, variabel dependen $(Y)$ dalam penelitian ini adalah kinerja karyawan, dan variabel intervening $(Z)$ dalam penelitian ini adalah komitmen organisasional. Analisis jalur dilakukan dengan bantuan program statistik SPSS.

\section{Analisis dan Pembahasan}

\section{Uji Validitas dan Reliabilitas}

Uji validitas dilakukan kepada 10 orang sampel. $r_{\text {tabel }}$ dalam penelitian ini adalah sebesar 0,6320 $(n=$ $10, \alpha=5 \%$ ). Tabel 3 menyatakan hasil uji validitas.

Tabel 3

Uji Validitas

\begin{tabular}{ccccc}
\hline Variabel & Indikator & $R_{\text {hitung }}$ & $R_{\text {tabel }}$ & Keterangan \\
\hline Keadilan & $X_{1.1}$ & 0,861 & 0,6320 & Valid \\
Organisasional & $X_{1.2}$ & 0,754 & 0,6320 & Valid \\
& $X_{1.3}$ & 0,712 & 0,6320 & Valid \\
& $X_{1.4}$ & 0,757 & 0,6320 & Valid \\
& $X_{1.5}$ & 0,834 & 0,6320 & Valid \\
Komitmen & $X_{2.1}$ & 0,821 & 0,6320 & Valid \\
Organisasional & $X_{2.2}$ & 0,715 & 0,6320 & Valid \\
& $X_{2.3}$ & 0,821 & 0,6320 & Valid \\
Kinerja & $X_{2.4}$ & 0,681 & 0,6320 & Valid \\
Karyawan & $Y_{1.1}$ & 0,701 & 0,6320 & Valid \\
& $Y_{1.2}$ & 0,648 & 0,6320 & Valid \\
& $Y_{1.3}$ & 0,586 & 0,6320 & Valid \\
& $Y_{1.4}$ & 0,758 & 0,6320 & Valid \\
& $Y_{1.5}$ & 0,724 & 0,6320 & Valid \\
& $Y_{1.6}$ & 0,779 & 0,6320 & Valid \\
& $Y_{1.7}$ & 0,861 & 0,6320 & Valid \\
& $Y_{1.8}$ & 0,581 & 0,6320 & Valid \\
& $Y_{1.9}$ & 0,818 & 0,6320 & Valid \\
\hline
\end{tabular}

Tabel 3 menunjukkan bahwa semua indikator dari tiap variabel adalah valid, karena memiliki $r_{\text {hitung }}$ yang lebih besar dari $r_{\text {tabel }}(0,6320)$, sehingga dapat dilakukan analisis selanjutnya. Tabel 4 menunjukkan hasil uji reliabilitas.
Tabel 4 menunjukkan bahwa nilai Alpha Cronbach tiap variabel memiliki nilai lebih dari 0,70 yang berarti reliabel, sehingga dapat dilakukan analisis selanjutnya.

Tabel 4

Uji Reliabilitas

\begin{tabular}{lccc}
\hline \multicolumn{1}{c}{ Variabel } & $\begin{array}{c}\text { Alpha } \\
\text { Cronbach }\end{array}$ & $\begin{array}{c}\text { Nilai } \\
\text { Kritis }\end{array}$ & Keterangan \\
\hline $\begin{array}{l}\text { Kedilan Organisasional } \\
\text { Komitmen Organisasio- }\end{array}$ & 0,916 & 0,70 & Reliabel \\
nal & 0,893 & 0,70 & Reliabel \\
Kinerja Karyawan & 0,920 & 0,70 & Reliabel \\
\hline
\end{tabular}

\section{Uji Asumsi Klasik}

Tabel 5 menunjukkan hasil uji multikolinearitas;

Tabel 5

Uji Multikolinearitas

\begin{tabular}{ccc}
\hline Variabel & Tolerance & VIF \\
\hline Kedilan Organisasional & 0,445 & 2,247 \\
Komitmen Organisasional & 0,445 & 2,247 \\
\hline
\end{tabular}

Variabel keadilan organisasional dan komitmen organisasional memiliki nilai $V I F=2,247$. Nilai $V I F$ yang kurang dari 10 dapat dikatakan tidak terjadi multikolinearitas sehingga antar variabel independen dalam penelitian ini tidak terjadi multikolinearitas.

Hasil perhitungan menunjukkan nilai DurbinWatson sebesar 1,616 dan nilai $d U=1,5937(k=2, n$ $=38$ ). Dari nilai tersebut, maka dapat disimpulkan bahwa tidak terjadi autokorelasi baik positif maupun negatif, karena nilai Durbin-Watson berada pada area $d u<d<4-d u$. Gambar 4 menunjukkan bahwa titiktitik pada plot menyebar secara acak baik di bawah maupun di atas sumbu $Y$, maka dapat disimpulkan tidak terjadi heteroskedastisitas.

Uji normalitas berguna untuk mengetahui apakah residual berdistribusi normal atau tidak. Hasil uji Kolmogorov-Smirnov menghasilkan nilai 0,096 dengan signifikansi 0,200. Dapat disimpulkan bahwa data pada penelitian ini berdistribusi normal, karena tingkat signifikansinya lebih dari 0,05 .

\section{Analisis Deskriptif}

Analisa deskriptif digunakan untuk mengetahui rata-rata nilai jawaban dari tiap variabel, yaitu variabel Keadilan Organisasional $\left(X_{I}\right)$, Komitmen Organisasional $\left(X_{2}\right)$, dan Kinerja Karyawan $(Y)$. Tabel 6 menunjukkan mean jawaban responden pada variabel keadilan organisasional, Tabel 7 menunjukkan mean jawaban responden pada variabel komitmen organisasional, dan Tabel 8 menunjukkan mean jawaban responden pada variabel kinerja karyawan. Sebagai 
standar tinggi rendahnya mean, maka dihitung interval kelasnya, melalui rumus:

Interval kelas $=\frac{\text { nilai tertinggi }- \text { nilai terendah }}{\text { banyak } \text { kelas interval }}=\frac{5-1}{5}=0,8$

Interval kelas 0,8 , maka 1,00-1,80 tergolong sangat rendah, 1,81-2,60 tergolong rendah, 2,61-3,40 tergolong sedang, 3,41-4,20 tergolong tinggi, dan $4,20-5,00$ tergolong sangat tinggi.

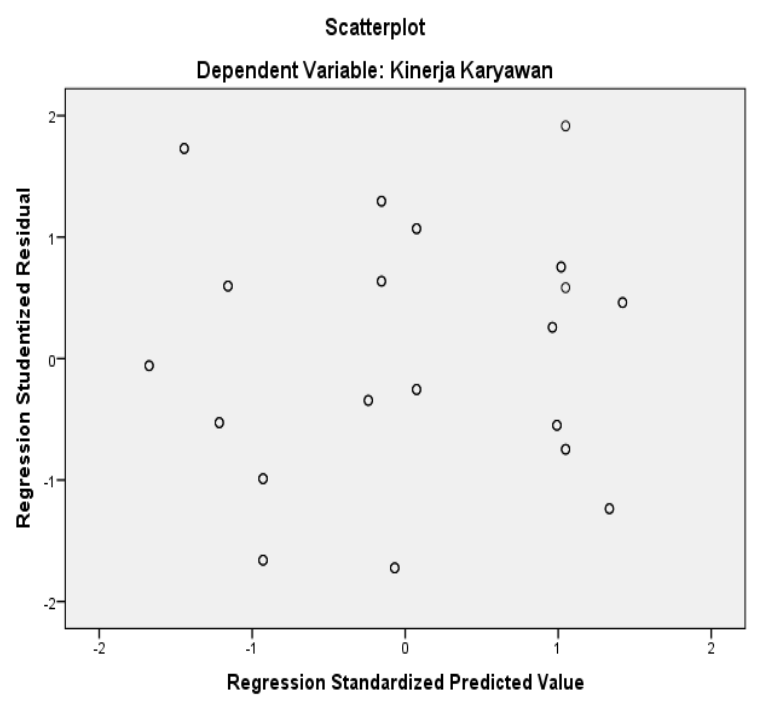

Gambar 4. Scatterplot ZPRED-SDRESID

Tabel 6

Deskriptif Jawaban Responden pada Variabel Keadilan Organisasional

\begin{tabular}{|c|c|c|c|c|}
\hline Indikator & Pernyataan & Mean & $\begin{array}{l}\text { Std. } \\
\text { Dev }\end{array}$ & Kategori \\
\hline$X_{1.1}$ & $\begin{array}{l}\text { Saya merasa gaji } \\
\text { yang saya terima } \\
\text { sesuai dengan } \\
\text { pekerjaan yang saya } \\
\text { selesaikan. }\end{array}$ & 3,21 & 1,119 & Sedang \\
\hline$X_{1.2}$ & $\begin{array}{l}\text { Saya merasa } \\
\text { keputusan di dalam } \\
\text { perusahaan } \\
\text { dilaksanakan sama } \\
\text { pada tiap pekerja. }\end{array}$ & 3,42 & 1,056 & Tinggi \\
\hline$X_{1.3}$ & $\begin{array}{l}\text { Saya diberikan } \\
\text { kesempatan untuk } \\
\text { menyuarakan } \\
\text { pendapat. }\end{array}$ & 2,79 & 1,255 & Sedang \\
\hline$X_{1.4}$ & $\begin{array}{l}\text { Saya merasa } \\
\text { diperlakukan atasan } \\
\text { sama dengan } \\
\text { karyawan yang lain. }\end{array}$ & 3,26 & 1,032 & Sedang \\
\hline$X_{1.5}$ & $\begin{array}{l}\text { Atasan saya tidak } \\
\text { menutup-nutupi } \\
\text { informasi dari saya. }\end{array}$ & 3,37 & 1,149 & Sedang \\
\hline & Rata-rata & 3,2105 & & Sedang \\
\hline
\end{tabular}

Tabel 7

Deskriptif Jawaban Responden pada Variabel Komitmen Organisasional

\begin{tabular}{clccc}
\hline $\begin{array}{c}\text { Indi- } \\
\text { kator }\end{array}$ & \multicolumn{1}{c}{ Pernyataan } & Mean & $\begin{array}{c}\text { Std. } \\
\text { Dev }\end{array}$ & Kategori \\
\hline$X_{2.1}$ & $\begin{array}{l}\text { Nilai-nilai yang saya } \\
\text { anut sesuai dengan } \\
\text { nilai-nilai yang } \\
\text { dimiliki oleh } \\
\text { perusahaan. } \\
X_{2.2}\end{array}$ & $\begin{array}{l}\text { Saya bersedia } \\
\text { melakukan pekerjaan } \\
\text { apa saja selama } \\
\text { pekerjaan tersebut } \\
\text { mendukung tujuan } \\
\text { perusahaan. }\end{array}$ & 0,933 & Sedang \\
$X_{2.3}$ & $\begin{array}{l}\text { Saya bangga telah } \\
\text { memilih perusahaan } \\
\text { ini sebagai tempat } \\
\text { kerja. }\end{array}$ & 3,32 & 0,933 & Sedang \\
$X_{2.4}$ & $\begin{array}{l}\text { Saya mempunyai } \\
\text { keinginan untuk tetap } \\
\text { bekerja di perusahaan } \\
\text { ini. }\end{array}$ & 3,68 & 1,188 & Sedang \\
\hline Rata-rata & 3,2632 & & Tinggi \\
\hline & & & \\
\hline
\end{tabular}

Hasil perhitungan pada Tabel 6 menunjukkan bahwa keadilan organisasional di CV Tanaya Fiberglass tergolong sedang, yaitu memiliki rata-rata sebesar 3,2105. Hal ini berarti pelaksanaan keadilan organisasional di perusahaan sudah cukup baik. Poin indikator yang memiliki nilai mean paling rendah adalah adanya kesempatan bagi karyawan untuk menyuarakan pendapat, yaitu bernilai 2,79 . Hal ini berarti bahwa perusahaan belum memberikan kesempatan bagi karyawan untuk menyuarakan pendapat. Pemilik juga menyatakan bahwa instruksi yang diberikan pada karyawan berupa aturan dan instruksi dan hanya kepala bagian produksi yang biasanya diberikan kesempatan untuk memberikan masukan bagi pemilik untuk mengambil keputusan. Hal ini dilakukan dengan pertimbangan pemilik lebih mengetahui apa yang harus dilakukan oleh karyawan. Poin indikator yang memiliki nilai mean tertinggi adalah kesamaan pelaksanaan keputusan pada setiap karyawan di perusahaan. Hal ini berarti bahwa perusahaan sudah menerapkan keputusan dan aturan secara sama pada setiap karyawan. Sistem keadilan yang diterapkan perusahaan sekarang dinilai sudah cukup baik, karena karyawan tidak melakukan protes terhadap perusahaan. Terutama, mengenai pembagian gaji, yang merupakan hal mendasar, juga sudah dianggap cukup adil oleh karyawan. Dengan adanya keadilan di perusahaan, maka karyawan tidak saling iri satu dengan yang lainnya, sehingga potensi timbulnya konflik antar karyawan dapat ditekan. Akan 
tetapi, melihat dari data yang didapatkan, penerapan keadilan di CV Tanaya Fiberglass masih dapat ditingkatkan, terutama di bagian pelibatan karyawan, yang mempunyai nilai paling rendah.

Hasil perhitungan pada Tabel 7 menunjukkan bahwa komitmen organisasional di CV Tanaya Fiberglass tergolong sedang, yaitu memiliki rata-rata sebesar 3,2632. Artinya komitmen karyawan terhadap CV Tanaya Fiberglass cukup. Poin indikator yang memiliki nilai mean paling rendah adalah kebersediaan karyawan melakukan pekerjaan apa saja apabila mendukung tujuan perusahaan. Hal ini berarti karyawan hanya mau melakukan pekerjaan yang menjadi tugasnya, sesuai dengan aturan dan instruksi yang diberikan. Poin indikator yang memiliki nilai mean tertinggi adalah keinginan karyawan untuk tetap bekerja di perusahaan. Dapat dikatakan bahwa mayoritas karyawan ingin tetap bekerja di perusahaan dengan berbagai alasan masing-masing. Walaupun komitmen organisasional bernilai sedang, tetapi masih ada karyawan yang bekerja, terkadang, dengan malas, karena orientasinya bukan untuk tujuan perusahaan. Hal tersebut masih dapat ditingkatkan perusahaan.

Hasil perhitungan pada Tabel 8 menunjukkan bahwa kinerja karyawan CV Tanaya Fiberglass tergolong sedang, yaitu memiliki rata-rata sebesar 3,3275. Artinya kinerja karyawan CV Tanaya Fiberglass sudah cukup baik. Poin indikator yang memiliki nilai mean paling rendah adalah penguasaan bidang kerja bagian lain, yang berarti karyawan menguasai pekerjaan di bagian produksi. Hal tersebut terjadi karena perusahaan hanya memberikan pelatihan bagi karyawan produksi hal-hal yang diperlukan untuk pekerjaannya di bagian produksi, seperti pengoperasian mesin, packing, dan pemasangan, Halhal yang dikerjakan di bagian lain tidak pernah diajarkan secara langsung Poin indikator yang memiliki nilai mean tertinggi adalah kesesuaian jumlah hasil kerja dengan harapan perusahaan. Pemilik menyatakan bahwa harapan perusahaan adalah sesuai dengan permintaan dari konsumen dan selama ini, pekerjaan karyawan selalu dilakukan tepat waktu. Secara umum, kinerja karyawan di CV Tanaya Fiberglass sudah sesuai dengan harapan perusahaan, yaitu sesuai target permintaan konsumen, walaupun terkadang harus disertai dengan lembur kerja. Tugas karyawan di bagian produksi adalah membuat fiberglass sesuai pesanan dan memasang fiberglass tersebut apabila diminta oleh konsumen. Dari data yang didapatkan, karyawan lebih banyak dialokasikan untuk membuat pesanan dan sebagian sisanya untuk memasang, sehingga karyawan lebih ahli untuk membuat daripada memasang. Dalam proses pema- sangan, perusahaan hanya menunjuk beberapa karyawannya yang dianggap ahli. Apabila ada proyek yang besar, maka karyawan sisanya dikerahkan juga, tetapi harus dilatih dan diawasi oleh karyawan yang lainnya.

Tabel 8

Deskriptif Jawaban Responden pada Variabel Kinerja Karyawan

\begin{tabular}{|c|c|c|c|c|}
\hline $\begin{array}{l}\text { Indi- } \\
\text { kator }\end{array}$ & Pernyataan & Mean & $\begin{array}{l}\text { Std. } \\
\text { Dev }\end{array}$ & Kategori \\
\hline$Y_{1.1}$ & $\begin{array}{l}\text { Saya mengerjakan } \\
\text { suatu pekerjaan } \\
\text { dengan teliti dan rapi. }\end{array}$ & 3,68 & 0,662 & Tinggi \\
\hline$Y_{1.2}$ & $\begin{array}{l}\text { Saya merasa jumlah } \\
\text { hasil kerja saya sudah } \\
\text { sesuai dengan harapan } \\
\text { perusahaan. }\end{array}$ & 3,92 & 0,587 & Tinggi \\
\hline$Y_{1.3}$ & $\begin{array}{l}\text { Saya mampu } \\
\text { melaksanakan } \\
\text { pekerjaan dengan baik. }\end{array}$ & 3,39 & 0,755 & Sedang \\
\hline$Y_{1.4}$ & $\begin{array}{l}\text { Saya dapat menguasai } \\
\text { bidang tugas bagian } \\
\text { lain. }\end{array}$ & 2,68 & 0,989 & Sedang \\
\hline$Y_{1.5}$ & $\begin{array}{l}\text { Saya dapat dengan } \\
\text { cepat menyesuaikan } \\
\text { diri pada setiap } \\
\text { keputusan-keputusan } \\
\text { baru yang diambil } \\
\text { perusahaan. }\end{array}$ & 2,84 & 1,151 & Sedang \\
\hline$Y_{1.6}$ & $\begin{array}{l}\text { Saya dapat } \\
\text { melaksanakan } \\
\text { prosedur kerja dengan } \\
\text { baik. }\end{array}$ & 3,53 & 0,687 & Tinggi \\
\hline$Y_{1.7}$ & $\begin{array}{l}\text { Saya selalu mencari } \\
\text { cara penyelesaian } \\
\text { ketika saya mengalami } \\
\text { kebuntuan kerja. }\end{array}$ & 3,00 & 1,139 & Sedang \\
\hline$Y_{1.8}$ & $\begin{array}{l}\text { Saya taat terhadap } \\
\text { aturan dan prosedur } \\
\text { kerja yang ditetapkan } \\
\text { dalam suatu pekerjaan. }\end{array}$ & 3,63 & 0,589 & Tinggi \\
\hline$Y_{1.9}$ & $\begin{array}{l}\text { Saya memperhatikan } \\
\text { dan memahami } \\
\text { seluruh aturan } \\
\text { keselamatan kerja } \\
\text { yang ditetapkan } \\
\text { perusahaan. }\end{array}$ & 3,26 & 1,083 & Sedang \\
\hline & Rata-rata & 3,3275 & & Sedang \\
\hline
\end{tabular}

\section{Analisis Jalur}

Hipotesis pertama $\left(H_{l}\right)$ yang diuji adalah keadilan organisasional berpengaruh terhadap komitmen organisasional. Hipotesis ini diuji dengan menggunakan uji- $t$. Hasil perhitungan menunjukkan $t_{\text {hitung }}=$ 19,110 dengan signifikansi 0,000, artinya keadilan organisasional berpengaruh terhadap komitmen organisasional $\left(H_{l}\right.$ terbukti). Persamaan yang dibentuk adalah sebagai berikut: 


$$
\begin{gathered}
Z=\alpha_{2}+a X \\
Z=0,366+0,902 X
\end{gathered}
$$

Keterangan:

$X=$ Keadilan Organisasional

$Z=$ Komitmen Organisasional

$\alpha_{2}=$ Konstanta, bernilai 0,366; artinya apabila keadilan organisasional bernilai 0 , maka nilai komitmen organisasional adalah 0,366

$a=$ Koefisien X, bernilai 0,902; artinya setiap kenaikan keadilan organisasional sebanyak satu satuan, maka menyebabkan kenaikan komitmen organisasional sebesar 0,902 .

Hipotesis kedua $\left(\mathrm{H}_{2}\right)$ yang diuji adalah keadilan organisasional dengan komitmen organisasional sebagai variabel intervening berpengaruh terhadap kinerja karyawan. Hasil perhitungan menunjukkan $t_{\text {hitumg }}=4,810$ dengan signifikansi 0,000 untuk variabel keadilan organisasional dan $t_{\text {hitung }}=2,193$ dengan signifikansi 0,035 untuk variabel komitmen organisasional, artinya keadilan organisasional dengan komitmen organisasional sebagai variabel intervening berpengaruh terhadap kinerja karyawan $\left(\mathrm{H}_{2}\right.$ terbukti). Persamaan yang dapat dibentuk adalah sebagai berikut:

$$
\begin{gathered}
Y=\alpha_{3}+c^{\prime} X+b Z \\
Y=1,088+0,468 X+0,226 Z
\end{gathered}
$$

Keterangan:

$X=$ Keadilan Organisasional

$Y=$ Kinerja Karyawan

$Z=$ Komitmen Organisasional

$\alpha_{3}=$ Konstanta, bernilai 1,088 ; artinya apabila keadilan organisasional dan komitmen organisasional bernilai 0 , maka nilai kinerja karyawan adalah 1,088

$c^{\prime}=$ Koefisien $X$, bernilai 0,468 ; artinya apabila komitmen organisasional konstan, setiap kenaikan keadilan organisasional sebanyak satu satuan, maka menyebabkan kenaikan kinerja karyawan sebesar 0,468.

$b=$ Koefisien $Z$, bernilai 0,226 ; artinya apabila keadilan organisasional konstan, setiap kenaikan komitmen organisasional sebanyak satu satuan, maka menyebabkan kenaikan kinerja karyawan sebesar 0,226.

Hipotesis ketiga $\left(\mathrm{H}_{3}\right)$ yang diuji adalah keadilan organisasional berpengaruh secara langsung terhadap kinerja karyawan. Hipotesis ini diuji dengan menggunakan uji-t. Hasil perhitungan menunjukkan $t_{\text {hitung }}=$ 21,912 dengan signifikansi 0,000 , artinya keadilan organisasional berpengaruh secara langsung terhadap kinerja karyawan $\left(H_{3}\right.$ terbukti). Persamaan yang dibentuk adalah sebagai berikut:

$$
\begin{gathered}
Y=\alpha_{1}+c X \\
Y=1,170+0,672 X
\end{gathered}
$$

Keterangan:

$X=$ Keadilan Organisasional

$Y=$ Kinerja Karyawan

$\alpha_{1}=$ Konstanta, bernilai 1,170; artinya apabila keadilan organisasional bernilai 0 , maka nilai kinerja karyawan adalah 1,170

$c=$ Koefisien $X$, bernilai 0,672 ; artinya setiap kenaikan keadilan organisasional sebanyak satu satuan, maka menyebabkan kenaikan kinerja karyawan sebesar 0,672.

Model pengujian hipotesis di atas, menghasilkan model analisis jalur seperti pada Gambar 5 .

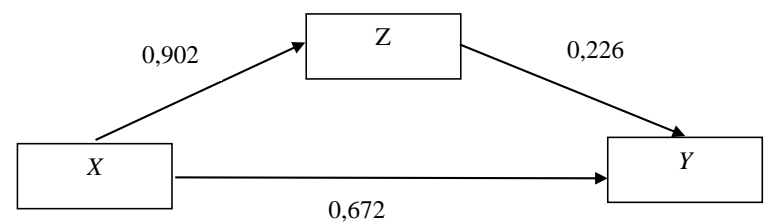

Gambar 5. Model Hubungan Keadilan Organisasional, Komitmen Organisasional, dan Kinerja Karyawan

Kuatnya pengaruh tidak langsung keadilan organisasional terhadap kinerja karyawan dapat dilakukan dengan dua cara, yaitu uji Sobel, yang dikemukakan oleh Sobel (1982) dan menyelisihkan koefisien langsung dengan koefisien tak langsung, yang dikemukakan oleh Judd and Kenny (1981). Keduanya menghasilkan nilai yang tidak jauh berbeda. Perhitungan kuatnya pengaruh tidak langsung dapat terlihat pada Tabel 9 yang menunjukkan hasil 0,204 .

Tabel 9

Perhitungan Kuatnya Pengaruh Tidak Langsung

\begin{tabular}{cc}
\hline Sobel (1982) & Judd and Kenny (1981) \\
\hline$a \times b=0,902 \times 0,226$ & $c-c^{\prime}=0,672-0,468$ \\
$=0,203852$ & $=0,204$ \\
\hline
\end{tabular}

Untuk melihat kecocokan model, maka dilihat pada hasil perhitungan koefisien determinasi $\left(R^{2}\right)$. Hasil perhitungan menunjukkan nilai koefisien determinasi adalah sebesar 0,935 . Artinya adalah kinerja karyawan ditentukan oleh keadilan organisasional dengan komitmen organisasional sebagai variabel intervening adalah sebesar 93,5\%; sedangkan sisa 6,5\%nya ditentukan oleh faktor-faktor lain yang tidak diteliti dalam penelitian ini.

\section{Pembahasan}

Hasil uji hipotesis menyatakan bahwa keadilan organisasional memiliki pengaruh terhadap komitmen 
organisasional. Artinya bahwa penerapan keadilan di CV Tanaya Fiberglass yang cukup adil membuat karyawan mempunyai komitmen terhadap perusahaan. Hal ini sejalan dengan penelitian Pareke dan Suryana (2009); Jawad et al. (2012); dan Yazicioglu and Topaloglu (2009) yang juga menyatakan bahwa keadilan organisasional mempunyai pengaruh positif dan signifikan terhadap komitmen organisasional. Keadilan memang diberlakukan bagi semua karyawan, seperti adanya standarisasi pemberian gaji, perlakuan yang sama pemilik kepada semua karyawan, dan penerapan aturan dan instruksi bagi karyawan di perusahaan. Hal tersebut juga dikonfirmasi oleh beberapa karyawan, yang menyatakan hal yang sama. Adanya perlakuan yang adil pada setiap karyawan dianggap karyawan dapat menciptakan situasi kerja yang baik, sehingga karyawan merasa betah bekerja di perusahaan. Yazicioglu and Topaloglu (2009) mengatakan bahwa dengan adanya keadilan di dalam organisasi, maka karyawan akan merasa nyaman saat bekerja di perusahaan dan bekerja dengan senang hati. Hal ini membuat karyawan mempunyai rasa memiliki (sense of belonging), yang mempunyai hubungan erat dengan komitmen, seperti kebanggaan terhadap perusahaan dan keinginan bertahan dalam perusahaan (Davila \& Jimenez 2012). Teori yang dikemukakan oleh Gibson et al. (2012) juga mendukung hasil penelitian, karena beberapa dampak yang diberikan dari adanya keadilan organisasional adalah meningkatnya komitmen terhadap organisasi, meningkatnya kesetiaan karyawan terhadap organisasi, dan karyawan akan mempercayai supervisor-nya.

Keadilan organisasional dengan komitmen organisasional sebagai variabel intervening berpengaruh terhadap kinerja karyawan. Hal ini sejalan dengan temuan Suliman and Kathairi (2013), yang juga menyatakan bahwa keadilan organisasional dengan komitmen organisasional sebagai variabel intervening berpengaruh terhadap kinerja karyawan. Adanya komitmen terhadap organisasi, yang dipengaruhi oleh keadilan organisasional, membuat kinerja karyawan menjadi lebih baik. Seperti dikatakan beberapa karyawan bahwa dengan adanya situasi kerja yang baik, yang tercipta karena adanya keadilan organisasional, maka dapat melakukan pekerjaan yang harus dikerjakan dengan lebih baik dan lebih maksimal, karena bekerja dengan senang hati. Akibatnya, proses produksi, baik kualitas dan kuantitas, maupun proses pelatihan karyawan dapat berjalan dengan baik. Situasi tersebut dirasakan karyawan yaitu bekerja tanpa terbeban. Sejalan dengan temuan dari Quirin, Donnelley, and O'Bryan (2001) yang menyatakan bahwa komitmen organisasi dapat memberikan dampak yang positif bagi tingkat kinerja karyawan.
Dengan mengetahui pengaruh keadilan organisasional dengan komitmen organisasional sebagai variabel intervening terhadap kinerja karyawan, maka dapat diketahui bahwa keadilan organisasional dan komitmen organisasional merupakan faktor penting yang dapat meningkatkan kinerja karyawan. Sekarang ini, keadilan di perusahaan dilakukan dengan memberikan upah yang sesuai dengan kinerjanya dan memperlakukan karyawan dengan sama. Hal tersebut dapat ditingkatkan dengan meminta aspirasi karyawan dengan berdiskusi mengenai masalah perusahaan, terutama di bagian produksi. Cara ini akan berguna bagi perusahaan juga, selain dapat meningkatkan komitmen organisasional dan kinerja karyawan.

\section{Simpulan}

Berdasarkan hasil penelitian yang dilakukan di CV Tanaya Fiberglass, maka dapat diambil simpulan, yaitu keadilan organisasional berpengaruh positif terhadap komitmen organisasional. Keadilan organisasional dengan komitmen organisasional sebagai variabel intervening berpengaruh positif terhadap kinerja karyawan. Keadilan organisasional berpengaruh positif terhadap kinerja karyawan.

\section{Daftar Referensi}

American Architectural Manufacturer Association. (2012). Fiberglass for fenestration. USA: AAMA.

Amin, A., Yusnita, Y., Ibrahim, M. Y., \& Muda, S. (2013). Transformational leadership and life satisfaction among homestay participants program: The mediating effect of attitude. International Journal of Business and Social Science, 4 (3), 235-243.

Atmojo, M. (2012). The influence of transformational leadership on job satisfaction, organizational commitment, and employee performance. International Research Journal of Business Studies, 5 (2), 113-128.

Carlis, Y. (2011). Pengaruh budaya organisasi terhadap komitmen organisasional pada RSUD Kabupaten Aceh Tamiang. Tesis. Sumatera Utara: Universitas Sumatera Utara.

Colquitt, J. A., LePine, J. A., \& Wesson, M. J. (2009). Organizational behavior: Improving performance and commitment in the workplace. United States: McGraw-Hill.

Davila, M. C., \& Jimenez, G. G. (2012). Organizational identification and commitment: Correlates of sense of belonging and affective commitment. US: PubMed. 
Dessler, G. (2005). Human resource management. United Kingdom: Pearson Education.

Fleming, S. (2000). From Personnel Management to HRM: Key Issues and Challenges. Retrieved from March 14, 2014 from http://www.cpmr.gov. ie/CPMRDiscussionPapers/paper16.doc.

Galuh, I. (2012). Konflik pengusaha buruh terkait upah minimum jangan sampai mengganggu investasi. Retrieved March 14, 2014 from http:// suarapengusaha.com/2012/11/27/konflik-pengusaha-buruh-terkait-upah-minimum-jangan-sampai-mengganggu-investasi/.

Ghozali, I. (2012). Aplikasi analisis multivariate dengan program IBM SPSS. Semarang: Badan Penelitian Universitas Diponegoro.

Gibson, J. L., Donnelly, J. H., Ivancevich, J. M., \& Konopaske, R. (2012). Organizations: Behavior, structure, processes. Singapore: McGraw-Hill.

Ginting, R. M. (2012). Pengaruh karakteristik peserta pelatihan \& karakteristik lingkungan kerja terhadap kinerja pegawai melalui transfer pelatihan pada PT Telkom Kandatel Me \&. Tesis. Pascasarjana Universitas Sumatera Utara.

Harahap, S. C. A. (2010). Pengaruh karakteristik individu, faktor organisasi \& faktor psikologis terhadap kinerja \& desa di kecamatan barumun tengah kabupaten tapanuli selatan Tahun 2008. Tesis. Pascasarjana Universitas Sumatera Utara.

Hellriegel, D., \& Slocum, J. W. (2004). Organizational behavior. Ohio: Thompson South-Western.

Jawad, M., Raja, S., Abraiz, A., \& Tabassum, T. M. (2012). Role of organizational justice in organizational commitment with moderating effect of employee work attitudes. IOSR Journal of Business and Management, 5(4), 39-45.

Judd, C. M., \& Kenny, D. A. (1981). Process analysis: Estimating mediation in treatment evaluations. Evaluation Review, 5(5), 602-619.

Li, A., \& Cropanzano, R. (2009). Fairness at the group level: Justice climate and intraunit justice climate. Journal of Management, 35, $564-599$.

Long, P. (1985). The unequal opportunities in personnel management. Equal Opportunities International, 4(2), 5-9.

Meyer, \& Allen 1997, Ignoring commitment is costly: New approaches establish the missing link between and performance. Human Relations, 50(6), 701-726.

Miller, B. K., Konopaske, R., \& Byrne, Z. S. (2012). Domiance analysis of two measures of organizational justice. Journal of Managerial Psychology, 27(3), 264-282.
Moorman, R. H. (1991). Relationship between organizational justice and organizational citizenship behaviors: Do fairness perceptions influence employee citizenship? Journal of Applied Psychology, 76(6), 845-855.

Moran, J. W., \& Brightman, B. K. (2000). Leading organizational change. Journal of Workplace Learning: Employee Counselling Today, 12(2), 66-74.

Nasurdin, A. M., \& Khuan, S. L. (2007). Organizational justice as an antecedent of job performance. Gadjah Mada International Journal of Business, 9(3), 335-353.

Neely, A., Adams, C., \& Crowe, P. (2001). The performance prism in practice. Measuring Business Excellent, 5(2), 6-12.

Noor, J. (2011). Metodologi penelitian. Jakarta: Kencana.

Pareke, F. J., \& Suryana, P. (2009). Hubungan kausalitas antara keadilan organisasional, kepuasan kerja, \& komitmen organisasional. Trikonomika, 8(2), 96-102.

Purwanto, H. (2013). Sibuk Ngurus Togel, Karyawan Jadi Malas Bekerja. Retrieved March 14, 2014 fromhttp://beritajatim.com/hukum_kriminal/184 632/sibuk_ngurus_togel,_karyawan_jadi_malas _kerja.html\#.UyKZfM4RzNE.

Puspowarsito, H. A. H. (2008). Metode penelitian organisasi. Bandung: Humaniora.

Quirin, J. J., Donnelley, D. P, \& O’Bryan, D. (2001). Antecedents of organizational commitment: The role of perception of equity. Advances in Accounting Behavioral Research, 4, 261-280.

Saidani, B., \& Arifin, S. (2012). Pengaruh kualitas produk dan kualitas layanan terhadap kepuasan konsumen dan minat beli pada ranch market. Jurnal Riset Manajemen Sains Indonesia, 3(1), $1-22$.

Siagian, S. P. (2005). Organisasi \& manajemen. Jakarta: PT Gunung Agung.

Skitka, L. J., \& Bravo, J. (2005). An accessible identity approach to understanding fairness in organizational settings. In K. van den Bos, D. Steiner, D. Skarlicki \& S. Gillil and (Eds.). What motivates fairness in organizations? (pp. 105128). Greenwich, CT: Information Age Publishing.

Sobel, M. E. (1982). Asymptotic confidence intervals for indirect effects in structural equation models. Sociological Methodology. 13(1), 290-321.

Suliman, A., \& Kathairi, M. A. (2013). Organizational justice, commitment, and performance in developing countries. Employee Relations, 35(1), 98-115. 
Sutanto, E. M. (1999). The relationship between employee commitment and job performance. Jurnal Manajemen \& Kewirausahaan, 1(1), 47-55.

Tobing, D. S. K. L. (2009). Pengaruh komitmen organisasional \& kepuasan kerja terhadap kinerja karyawan PT Perkebunan Nusantara III di Sumatera Utara. Jurnal Manajemen \& Kewirausahaan, 11(1), 31-37.

Widiyanto, D. (2014). Konflik Pabrik La Dewindo Semakin Runyam. Retrieved March 14, 2014 from http://kr.co.id/read/207429/konflik-pabrikla-dewindo-semakin-runyam.kr.
Yazicioglu, I., \& Topaloglu, I. G. (2009). The relationship between organizational justice and commitment: A case study in accommodation establishments. Isletme Arastirmalan Dergisi, 1 (1), 3-16.

Zikmund, W. G., Babin, B. J., Carr, J. C., \& Griffin, M. (2010). Business research method. Canada: South-Western Cengage Learning.

Zopiatis, A., \& Constanti, P. (2007). Human resource challenge confronting the Cyprus hospitality industry. EuroMed Journal of Business, 2(2), 135-53. 